\title{
Quantification of Metal Contaminants and Risk Assessment in Some Urban Watersheds
}

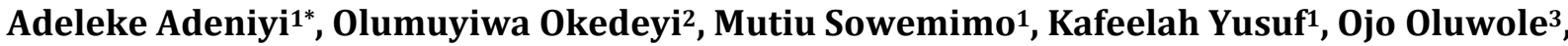 \\ Goodluck Odili ${ }^{3}$, Bernadine Ejiogu ${ }^{3}$, Iyabode Ajibade ${ }^{1}$, Bamitale Fabiyi' ${ }^{1}$, Olubunmi Adeniji ${ }^{3}$ \\ ${ }^{1}$ Department of Chemistry, Lagos State University, Ojo, Lagos, Nigeria \\ ${ }^{2}$ Department of Biochemistry, Lagos State University, Ojo, Lagos, Nigeria \\ ${ }^{3}$ Centre for Environmental Studies and Sustainable Development (CESSED), Lagos State University, Ojo, Lagos, Nigeria \\ Email: ^adeleke.adeniyi@lasu.edu.ng, „lekeadeniy@yahoo.com
}

How to cite this paper: Adeniyi, A., Okedeyi, O., Sowemimo, M., Yusuf, K., Oluwole, O., Odili, G., Ejiogu, B., Ajibade, I., Fabiyi, B. and Adeniji, O. (2020) Quantification of Metal Contaminants and Risk Assessment in Some Urban Watersheds. Journal of Water Resource and Protection, 12, 951-963.

https://doi.org/10.4236/jwarp.2020.1211056

Received: October 22, 2020

Accepted: November 24, 2020

Published: November 27, 2020

Copyright ( 2020 by author(s) and Scientific Research Publishing Inc. This work is licensed under the Creative Commons Attribution International License (CC BY 4.0).

http://creativecommons.org/licenses/by/4.0/ (c) (i) Open Access

\begin{abstract}
Contamination by heavy metals is a serious threat to aquatic systems due to their level of toxicity at elevated levels. The pollution of urban watersheds is of particular concern because of its potential impact on the watershed ecosystem and the receiving larger water bodies. This study assessed the occurrence and distribution of cadmium, copper, nickel, lead and zinc in water and sediment samples collected from three urban watersheds in Lagos, Nigeria. The concentrations of metals were determined using atomic absorption spectrometry. The health risk index (HRI) of water usage was evaluated for both adults and children. HRI for cadmium and lead in some of the watersheds recorded HRI $>1$ values, a cause for health concern. The $\mathrm{pH}$ of water ranged from $6.48 \pm 0.28-6.54 \pm 0.47(2016)$ and $6.18 \pm 0.56-6.53 \pm 0.17$ (2018) respectively while, for sediments, the $\mathrm{pH}$ values ranged from $6.14 \pm 0.48-6.9 \pm$ 0.15 and $5.38 \pm 0.22-6.4 \pm 0.38$ for 2016 and 2018 respectively. The levels of metals in the water samples during the 2016 sampling cycle were found to be within the World Health Organization (WHO) guideline limits for drinking water. However, the 2018 cadmium, lead and zinc concentrations for Ira-Ipaye and Akesan watersheds exceed the WHO guideline limits. Cadmium was not detected in Ira-Ipaye and Akesan 2016 sediment samples. Statistical t-test and analysis of variance (ANOVA) were used to ascertain significant differences of metals concentration in the three watersheds. The $\mathrm{pH}$ and metal concentration values obtained for water and sediment for the year 2016 and 2018 were non-significantly different.
\end{abstract}

\section{Keywords}

Metals, Cadmium, Lead, Watersheds, Health Risk 


\section{Introduction}

Watersheds are important in the study and management of environmental water resources [1] [2] [3] [4]. A water resource is of no value if the quality is degraded such that it prevents the desired water uses [5] [6].

Studies have shown that atmospheric deposition, vehicular transportation-related activities and metallic building envelopes resulting from agricultural, domestic and industrial activities are among the major pollution sources of urban watersheds [7] [8]. The partitioning of sources is further complicated by source interactions [9]. The fate of these metal pollutants in the biological systems is known to be equally influenced by dissolved organic matter [10] [11] [12]. Similarly, climatic conditions have been shown to affect the transport, enrichment and bioavailability of heavy metals in watersheds [13]. Consequently, pollution sources should be more closely controlled and monitored for the purposes of enhanced water quality and ecological conservation [7] [14] [15] [16].

Healthy watersheds support environmental and ecological functions, including societal services such as water availability, flood protection, healthy aquatic food products and recreation [17] [18] [19]. Metal pollution source control is the major mitigation strategy that is in vogue in decontaminating polluted watersheds [7] [8].

Cadmium and lead have no known functions in plants, animals or humans [20] [21]. These metals have been implicated as endocrine disruptors in humans and other organisms amongst other adverse health effects [22] [23] [24] [25]. The effects of elevated levels of nickel in humans are cardiovascular diseases, dizziness, lung and nasal cancers among other debilitating side effects [26]. As important as copper and zinc are as nutrients, high doses can result in side effects like depression, gastrointestinal irritation, kidney and liver failure [24] [25] [26]. On the other hand, even at low concentrations, zinc is reported to be intolerable to aquatic organisms especially fish [27] [28].

In the vicinity of the watersheds, land use is predominantly for residential purposes, small-scale farming and refined petroleum dispensing facilities. Whereas, the potential pollutant sources are direct disposal of domestic and agricultural wastes, runoffs and vehicular traffic emissions [29] [30] [31]. Other possible non-point pollution sources are the Agbara industrial estate [32] and accidental leakages from petroleum storage facilities and pipelines [33].

The aim of this study was to evaluate the occurrence and distribution of cadmium, copper, nickel, lead and zinc in water and sediment samples of three urban watersheds; with a view to determine the extent of metal pollution exacerbation over the two-year period, 2016 to 2018, the health risk indices would also be evaluated. The outcome of this study would assist the relevant government agencies to formulate an efficient monitoring strategy for watersheds in line with global best practices.

\section{Materials and Methods}

Study area: Ira-Ipaye and Agboroko watersheds are located along the ev- 
er-busy Isheri-LASU expressway, in the Ojo Local Government Area, of Lagos State, Nigeria. While the Akesan watershed is situated off the Isheri-LASU expressway but in the Alimosho Local Government Area, Lagos State. The global positioning system (GPS) data are indicated in Table 1 and Table 2, and shown in Figure 1. Increasing human settlements coupled with increased commercial and agricultural activities necessitated the choice of the three watersheds. The watersheds empty into the Obadore River enroute Ishashi/Agbara Rivers.

Sampling: Composite replicate samples each of both water and sediment samples were collected randomly once a week, for the period of five weeks respectively from the watersheds, between the months of September and October (2016); January and February (2018).

Water and sediment samples were collected following the standard procedures described by America Public Health Association [34] and Department of Water Affairs and Forestry [35]. Sediment samples were air-dried and sieved using 0.45 $\mu \mathrm{m}$ mesh sieve [28] [36] [37]. The $\mathrm{pH}$ of the water and sediment samples was determined using the Hanna $\mathrm{pH}$ meter. Plastic containers were used to collect

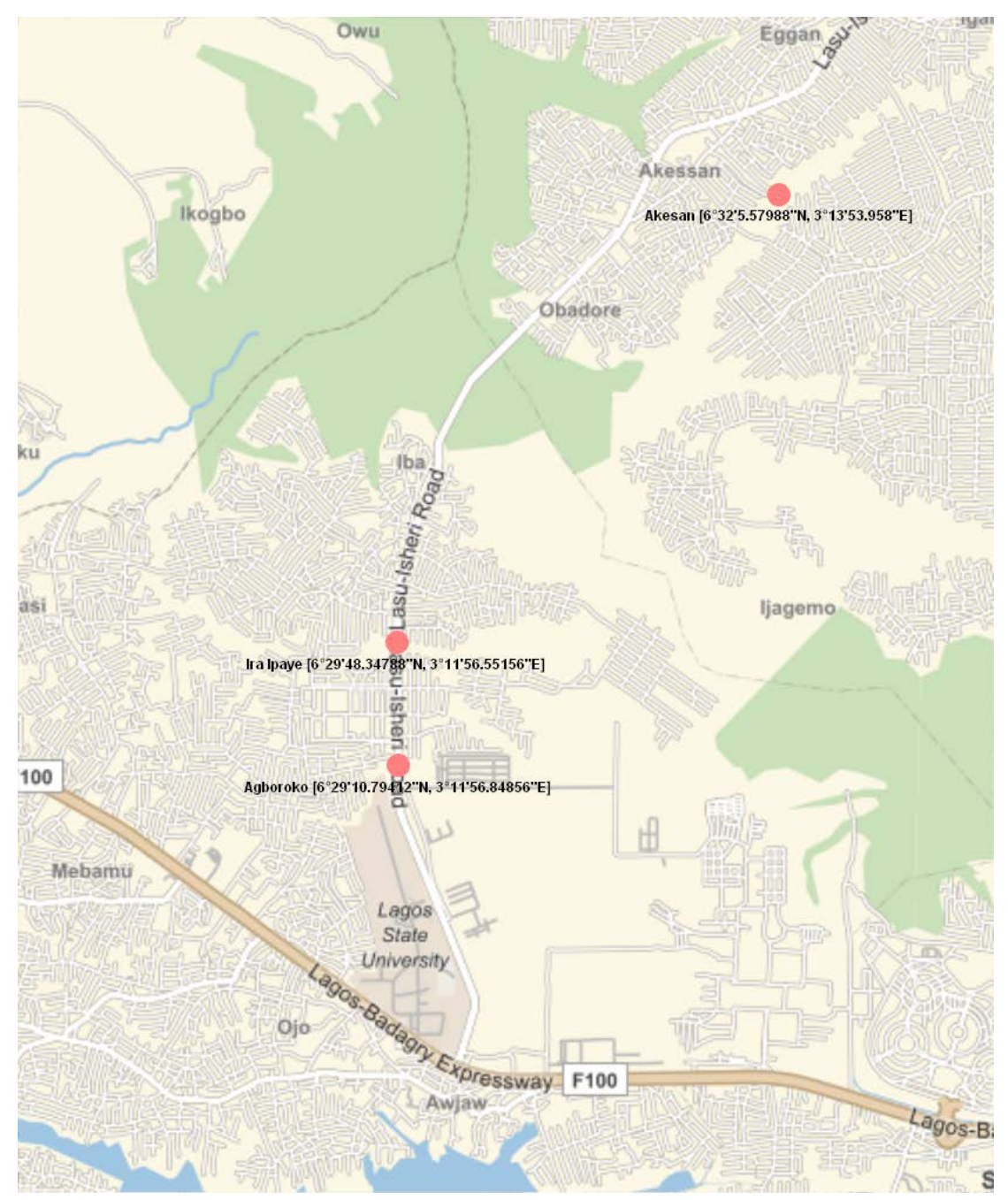

Figure 1. Map of sampling locations. 
and store water samples, with $10 \mathrm{ml}$ nitric acid added immediately. The samples were transported from the field to the laboratory for analysis. The samples were kept at $5^{\circ} \mathrm{C}$ in the refrigerator until they were analyzed at the laboratory [33].

The samples were prepared for metal analysis using acid digestion as described earlier [27] [33]. Five heavy metals-cadmium, copper, nickel, lead and zinc were determined in an air-acetylene flame (Atomic Absorption Spectrophotometer (AAS) Model: Buck 210 VGP).

Quality control of analytical data: High purity chemicals and reagents (purchased from Merck and Aldrich Chemical company), together with distilled-deionized water were used. Stock solutions (Merck) of $1000 \mathrm{mg} / \mathrm{L}$ of the different metals were used to prepare the calibration standards. Pre-digested water and sediment samples were spiked with metal standards in triplicate for metal recovery studies as reported earlier [27] [38]. The AAS setting and operational conditions were done in accordance with the manufacturer's specifications, and were calibrated with analytical grade standard solutions $(1000 \mathrm{mg} / \mathrm{L})$ after appropriate dilutions.

Statistical analysis: To estimate statistically significant differences between the 2016 and 2018 samples and within the respective watersheds, $t$-test and ANOVA statistical analyses at $\mathrm{p}<0.05$ levels of significance were employed [39]. The values are presented in Tables 5-7 respectively.

Risk assessment: To assess the potential health risks for adults and children, health risk indicators, such as chronic daily intakes (CDI) and health risk index (HRI) were calculated for the water samples [40] [41].

$$
\mathrm{CDI}\left(\mathrm{mg} \cdot \mathrm{kg}^{-1} \cdot \mathrm{day}^{-1}\right)=C_{m} \cdot I_{w} / W_{b}
$$

where $C_{m}\left(\mathrm{mg} \cdot \mathrm{L}^{-1}\right)=$ metal concentration in water; $I_{W}\left(\mathrm{~L} \cdot\right.$ day $\left.^{-1}\right)=$ average daily intake of water (assumed to be $2 \mathrm{~L} \cdot \mathrm{day}^{-1}$ for an adult and $1 \mathrm{~L} \cdot \mathrm{day}^{-1}$ for a child); $W_{b}=$ average body weights (assumed to be $72 \mathrm{~kg}$ for an adult and $32.7 \mathrm{~kg}$ for a child). The CDI data are shown in Table 8 and Table 9.

$$
\mathrm{HRI}=\mathrm{CDI} / \mathrm{RfD}
$$

where the oral toxicity reference dose ( $\left.\mathrm{RfD}, \mathrm{mg} \cdot \mathrm{kg}^{-1}\right)$, the values are: $\mathrm{Cd}, \mathrm{Cu}, \mathrm{Ni}$, $\mathrm{Pb}$ and $\mathrm{Zn} ; 1 \times 10^{-3}, 4 \times 10^{-2}, 2 \times 10^{-2}, 4 \times 10^{-3}, 3 \times 10^{-1}$ respectively. The HRI values are listed in Table 10 and Table 11.

\section{Results and Discussion}

\subsection{Results}

Table 1. Sampling locations and the result of some chemical parameters in the water samples of the three watersheds (2016).

\begin{tabular}{ccccccc}
\hline & \multicolumn{1}{c}{} & & & $\mu \mathrm{g} / \mathrm{L}$ \\
\hline Location/GPS & $\mathrm{pH}$ & $\mathrm{Cd}$ & $\mathrm{Cu}$ & $\mathrm{Ni}$ & $\mathrm{Pb}$ & $\mathrm{Zn}$ \\
\hline $\begin{array}{c}\text { Ira-Ipaye } \\
6^{\circ} 29^{\prime} 48.34788^{\prime \prime N}\end{array}$ & $6.48 \pm 0.28$ & $\mathrm{ND}$ & $8.0 \pm 8.61$ & $\mathrm{ND}$ & $14.0 \pm 31.3$ & $238.0 \pm 209.9$ \\
$3^{\circ} 11^{\prime} 56.55156 " \mathrm{E}$ & & & & & & \\
\hline
\end{tabular}




\section{Continued}

\begin{tabular}{ccccccc}
\hline $\begin{array}{c}\text { Agboroko } \\
6^{\circ} 29^{\prime} 10.79412 " \mathrm{~N}\end{array}$ & $6.48 \pm 0.16$ & $0.02 \pm 0.04$ & $0.46 \pm 0.29$ & $0.14 \pm 0.1$ & $0.12 \pm 0.19$ & $0.86 \pm 1.12$ \\
$3^{\circ} 11^{\prime} 56.84856 " \mathrm{E}$ & & & & & & \\
Akesan & & & & & & \\
$6^{\circ} 32^{\prime} 5.57988^{\prime \prime} \mathrm{N}$ & $6.54 \pm 0.47$ & $\mathrm{ND}$ & $54 \pm 22.45$ & $\mathrm{ND}$ & $\mathrm{ND}$ & $310 \pm 123.94$ \\
$3^{\circ} 13^{\prime} 53.958^{\mathrm{E}} \mathrm{E}$ & & & & & & \\
WHO & & & & & & \\
Guideline & $6.5-8.5$ & 5.0 & 5000.0 & 70.0 & 50.0 & 5000.0 \\
Limit & & & & & & \\
\hline
\end{tabular}

Notes: ND, not detected; WHO, World Health Organization; GPS, Global positioning system data (latitude; longitude).

Table 2. Sampling locations and the result of some chemical parameters in the water samples of the three watersheds (2018).

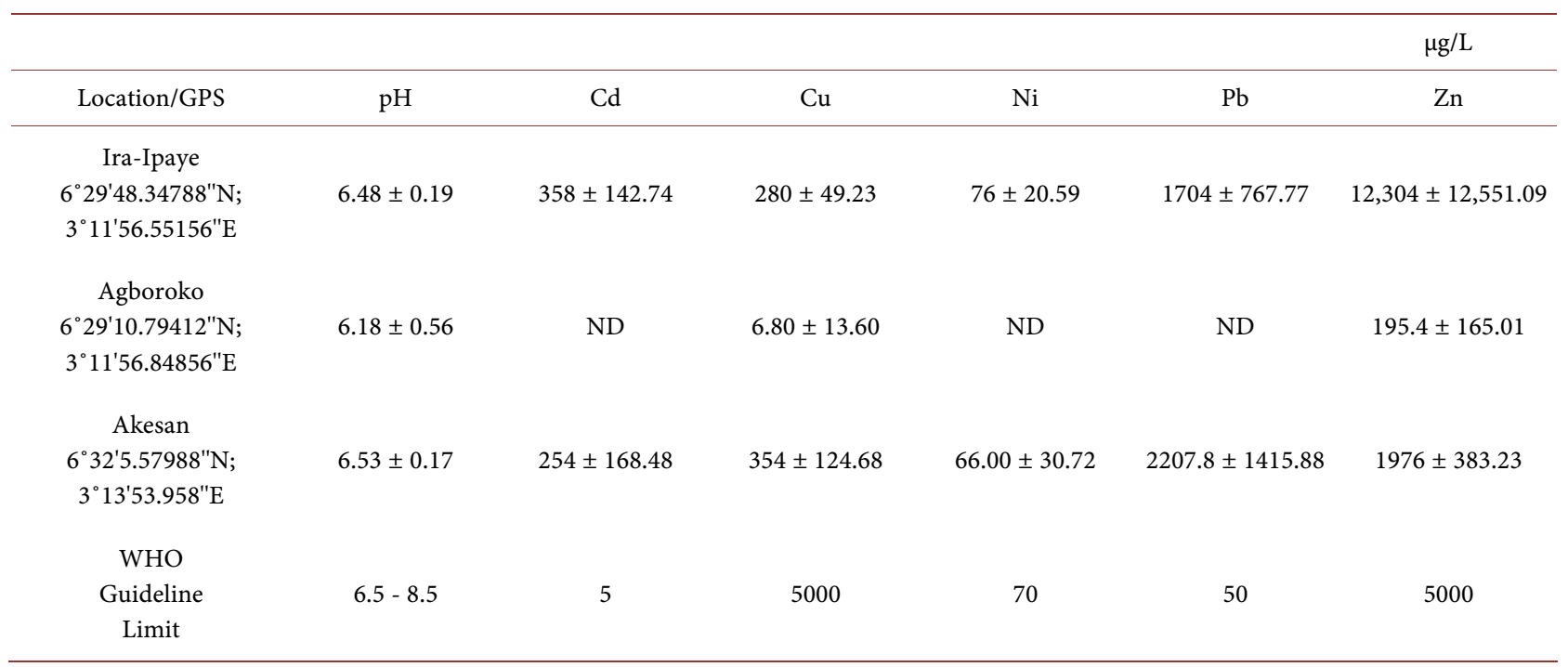

Table 3. Sampling locations and the result of some chemical parameters in the sediment samples of the three watersheds (2016).

\begin{tabular}{ccccccc}
\hline & & & & & $\mathrm{ng} / \mathrm{g}$ \\
\hline Location & $\mathrm{pH}$ & $\mathrm{Cd}$ & $\mathrm{Cu}$ & $\mathrm{Ni}$ & $\mathrm{Pb}$ & $\mathrm{Zn}$ \\
\hline Ira-Ipaye & $6.14 \pm 0.48$ & $\mathrm{ND}$ & $6790 \pm 1673.02$ & $4016 \pm 1428$ & $11,818 \pm 1050$ & $14,890 \pm 3242.92$ \\
Agboroko & $6.9 \pm 0.15$ & $1.04 \pm 0.77$ & $95 \pm 48$ & $29.38 \pm 5.50$ & $508.98 \pm 248.05$ & $691 \pm 43$ \\
Akesan & $6.8 \pm 0.17$ & $\mathrm{ND}$ & $20,310 \pm 5021$ & $5730 \pm 1562.24$ & $24,324 \pm 6832.63$ & $169,110 \pm 43,216.29$ \\
\hline
\end{tabular}

Table 4. Sampling locations and the result of some chemical parameters in the sediment samples of the three watersheds (2018).

\begin{tabular}{|c|c|c|c|c|c|c|}
\hline & & & & & & $\mathrm{ng} / \mathrm{g}$ \\
\hline Location & $\mathrm{pH}$ & $\mathrm{Cd}$ & $\mathrm{Cu}$ & $\mathrm{Ni}$ & $\mathrm{Pb}$ & $\mathrm{Zn}$ \\
\hline Ira-Ipaye & $5.47 \pm 0.52$ & $1662 \pm 514.99$ & $5760 \pm 2900.28$ & $640 \pm 293$ & $14,444 \pm 6763$ & $22,732 \pm 23,806$ \\
\hline Agboroko & $6.4 \pm 0.38$ & $\mathrm{ND}$ & $6935 \pm 4584$ & ND & $21,540 \pm 8026.43$ & $4761.8 \pm 2175.6$ \\
\hline Akesan & $5.38 \pm 0.22$ & $3388 \pm 170.69$ & $8340 \pm 724.51$ & $1500 \pm 142.83$ & $20,996 \pm 3417$ & $20,878 \pm 2795$ \\
\hline
\end{tabular}

Note: ND, not detected. 
Table 5. t-test (95\% confidence level) of $\mathrm{pH}$ and metals in 2016 vs 2018 water and sediments samples.

\begin{tabular}{ccccccc}
\hline Location & $\mathrm{pH}$ & $\mathrm{Cd}$ & $\mathrm{Cu}$ & $\mathrm{Ni}$ & $\mathrm{Pb}$ & $\mathrm{Zn}$ \\
\hline \multirow{2}{*}{ Ira-Ipaye } & 0.49 & 0.004 & 0.0004 & 0.001 & 0.006 & 0.33 \\
& $(0.06)$ & $(0.001)$ & $(0.26)$ & $(0.007)$ & $(0.23)$ & $(0.26)$ \\
Agboroko & 0.20 & 0.19 & 0.20 & 0.03 & 0.14 & 0.04 \\
& $(0.07)$ & $(0.03)$ & $(0.02)$ & $(0.0001)$ & $(0.003)$ & $(0.01)$ \\
Akesan & 0.47 & 0.02 & 0.006 & 0.006 & 0.02 & 0.001 \\
& $(0.001)$ & $(0.000001)$ & $(0.003)$ & $(0.003)$ & $(0.21)$ & $(0.001)$ \\
\hline
\end{tabular}

Note: values in parentheses are for sediments; $\mathrm{t}_{\mathrm{tab}}=2.31$.

Table 6. ANOVA of metal levels in water and sediment in the three watersheds (2016).

\begin{tabular}{cccccccc}
\hline & $\mathrm{pH}$ & $\mathrm{Cd}$ & $\mathrm{Cu}$ & $\mathrm{Ni}$ & $\mathrm{Pb}$ & $\mathrm{Zn}$ & $\begin{array}{c}\text { F-critical } \\
(\mathrm{p}<0.05)\end{array}$ \\
\hline Water & $0.07^{\mathrm{ns}}$ & $1.0^{\mathrm{ns}}$ & $15.53^{*}$ & $9.39^{*}$ & $0.99^{\mathrm{ns}}$ & $4.61^{*}$ & 3.89 \\
Sediment & $5.36^{*}$ & $7.38^{*}$ & $45.39^{*}$ & $22.92^{*}$ & $35.39^{*}$ & $55.75^{\star}$ & \\
\hline
\end{tabular}

Notes: ns, non-significant difference at $\mathrm{p}<0.05$; ${ }^{\star}$ significant difference at $\mathrm{p}<0.05$.

Table 7. ANOVA of metal levels in water and sediment in the three watersheds (2018).

\begin{tabular}{cccccccc}
\hline & $\mathrm{pH}$ & $\mathrm{Cd}$ & $\mathrm{Cu}$ & $\mathrm{Ni}$ & $\mathrm{Pb}$ & $\mathrm{Zn}$ & $\begin{array}{c}\text { F-critical } \\
(\mathrm{p}<0.05)\end{array}$ \\
\hline Water & $0.15^{\mathrm{ns}}$ & $0.03^{\mathrm{ns}}$ & $0.03^{\mathrm{ns}}$ & $0.002^{\mathrm{ns}}$ & $1.76^{\mathrm{ns}}$ & $81.06^{*}$ & 3.89 \\
Sediment & $0.59^{\mathrm{ns}}$ & $2.01^{\mathrm{ns}}$ & $11.10^{\star}$ & $0.41^{\mathrm{ns}}$ & $51.01^{\star}$ & $258.20^{\star}$ & \\
\hline
\end{tabular}

Notes: ns, non-significant difference at $\mathrm{p}<0.05 ;{ }^{*}$ significant difference at $\mathrm{p}<0.05$.

Table 8. Chronic daily intakes (CDIs, $\mathrm{mg} \cdot \mathrm{kg}^{-1} \cdot \mathrm{day}^{-1}$ ) of metals through water consumption in 2016.

\begin{tabular}{|c|c|c|c|c|c|}
\hline Location & $\mathrm{Cd}$ & $\mathrm{Cu}$ & $\mathrm{Ni}$ & $\mathrm{Pb}$ & $\mathrm{Zn}$ \\
\hline Ira-Ipaye & - & $\begin{array}{l}22.2 \times 10^{-5} \pm 32.3 \times 10^{-5} \\
\left(24.5 \times 10^{-5} \pm 35.7 \times 10^{-5}\right)\end{array}$ & - & $\begin{array}{c}38.9 \times 10^{-5} \pm 77.8 \times 10^{-5} \\
\left(42.9 \times 10^{-5} \pm 85.8 \times 10^{-5}\right)\end{array}$ & $\begin{array}{c}646 \times 10^{-5} \pm 598 \times 10^{-5} \\
\left(728 \times 10^{-5} \pm 642 \times 10^{-5}\right)\end{array}$ \\
\hline Agboroko & $\begin{array}{c}0.005 \times 10^{-5} \pm 0.009 \times 10^{-5} \\
\left(0.006 \times 10^{-5} \pm 0.001 \times 10^{-5}\right)\end{array}$ & $\begin{array}{l}1.28 \times 10^{-5} \pm 0.82 \times 10^{-5} \\
\left(1.41 \times 10^{-5} \pm 0.9 \times 10^{-5}\right)\end{array}$ & $\begin{array}{c}0.04 \times 10^{-5} \pm 0.09 \times 10^{-5} \\
\left(0.04 \times 10^{-5} \pm 0.03 \times 10^{-5}\right)\end{array}$ & $\begin{array}{c}0.04 \times 10^{-5} \pm 0.06 \times 10^{-5} \\
\left(0.05 \times 10^{-5} \pm 0.06 \times 10^{-5}\right)\end{array}$ & $\begin{array}{l}2.39 \times 10^{-5} \pm 3.11 \times 10^{-5} \\
\left(2.63 \times 10^{-5} \pm 3.43 \times 10^{-5}\right)\end{array}$ \\
\hline Akesan & - & $\begin{array}{c}150 \times 10^{-5} \pm 62 \times 10^{-5} \\
\left(165 \times 10^{-5} \pm 69 \times 10^{-5}\right)\end{array}$ & - & - & $\begin{array}{r}861 \times 10^{-5} \pm 314 \times 10^{-5} \\
\left(948 \times 10^{-5} \pm 379 \times 10^{-5}\right)\end{array}$ \\
\hline
\end{tabular}

Note: values in parentheses are for children, others are for adults.

Table 9. Chronic daily intakes (CDIs, $\mathrm{mg} \cdot \mathrm{kg}^{-1} \cdot \mathrm{day}^{-1}$ ) of metals through water consumption in 2018.

\begin{tabular}{|c|c|c|c|c|c|}
\hline Location & $\mathrm{Cd}$ & $\mathrm{Cu}$ & $\mathrm{Ni}$ & $\mathrm{Pb}$ & $\mathrm{Zn}$ \\
\hline Ira-Ipaye & $\begin{array}{c}9.94 \times 10^{-3} \pm 3.97 \times 10^{-3} \\
\left(10.95 \times 10^{-3} \pm 4.37 \times 10^{-3}\right)\end{array}$ & $\begin{array}{c}6 \times 10^{-3} \pm 1.4 \times 10^{-3} \\
\left(6.66 \times 10^{-3} \pm 1.53 \times 10^{-3}\right)\end{array}$ & $\begin{array}{c}2.11 \times 10^{-3} \pm 0.57 \times 10^{-3} \\
\left(2.32 \times 10^{-3} \pm 0.63 \times 10^{-3}\right)\end{array}$ & $\begin{array}{c}47.3 \times 10^{-3} \pm 21.3 \times 10^{-3} \\
\left(52.1 \times 10^{-3} \pm 23.5 \times 10^{-3}\right)\end{array}$ & $\begin{array}{l}341.8 \times 10^{-3} \pm 348.6 \times 10^{-3} \\
\left(376.3 \times 10^{-3} \pm 383.8 \times 10^{-3}\right)\end{array}$ \\
\hline Agboroko & - & $\begin{array}{c}0.19 \times 10^{-3} \pm 0.38 \times 10^{-3} \\
\left(0.21 \times 10^{-3} \pm 0.42 \times 10^{-3}\right)\end{array}$ & - & - & $\begin{array}{c}5.43 \times 10^{-3} \pm 4.58 \times 10^{-3} \\
\left(5.98 \times 10^{-3} \pm 5.05 \times 10^{-3}\right)\end{array}$ \\
\hline Akesan & $\begin{array}{c}7.06 \times 10^{-3} \pm 4.68 \times 10^{-3} \\
\left(7.77 \times 10^{-3} \pm 5.15 \times 10^{-3}\right)\end{array}$ & $\begin{array}{c}9.83 \times 10^{-3} \pm 3.46 \times 10^{-3} \\
\left(10.83 \times 10^{-3} \pm 3.81 \times 10^{-3}\right)\end{array}$ & $\begin{array}{c}1.83 \times 10^{-3} \pm 0.85 \times 10^{-3} \\
\left(2.02 \times 10^{-3} \pm 0.94 \times 10^{-3}\right)\end{array}$ & $\begin{array}{c}61.3 \times 10^{-3} \pm 39.3 \times 10^{-3} \\
\left(67.5 \times 10^{-3} \pm 43.3 \times 10^{-3}\right)\end{array}$ & $\begin{array}{c}54.9 \times 10^{-3} \pm 10.6 \times 10^{-3} \\
\left(60.4 \times 10^{-3} \pm 11.7 \times 10^{-3}\right)\end{array}$ \\
\hline
\end{tabular}

Note: values in parentheses are for children, others are for adults. 
Table 10. Health risk index (HRI) of metals through water usage for 2016.

\begin{tabular}{cccccc}
\hline Location & $\mathrm{Cd}$ & $\mathrm{Cu}$ & $\mathrm{Ni}$ & $\mathrm{Pb}$ & $\mathrm{Zn}$ \\
\hline \multirow{2}{*}{ Ira-Ipaye } & - & $5.55 \mathrm{E}-03$ & & $9.72 \mathrm{E}-02$ & $2.15 \mathrm{E}-02$ \\
& & $(6.13 \mathrm{E}-03)$ & - & $(10.73 \mathrm{E}-02)$ & $(2.43 \mathrm{E}-02)$ \\
Agboroko & $5.0 \mathrm{E}-05$ & $3.2 \mathrm{E}-04$ & $1.95 \mathrm{E}-05$ & $1.1 \mathrm{E}-04$ & $7.97 \mathrm{E}-05$ \\
& $(6.0 \mathrm{E}-05)$ & $(3.53 \mathrm{E}-04)$ & $(2.15 \mathrm{E}-05)$ & $(1.23 \mathrm{E}-04)$ & $(8.77 \mathrm{E}-05)$ \\
& & $3.75 \mathrm{E}-02$ & & & $2.87 \mathrm{E}-02$ \\
Akesan & - & $(4.13 \mathrm{E}-02)$ & - & - & $(3.16 \mathrm{E}-02)$ \\
\hline
\end{tabular}

Note: values in parentheses are for children, others are for adults.

Table 11. Health risk index (HRI) of metals through water usage for 2018.

\begin{tabular}{cccccc}
\hline Location & $\mathrm{Cd}$ & $\mathrm{Cu}$ & $\mathrm{Ni}$ & $\mathrm{Pb}$ & $\mathrm{Zn}$ \\
\hline \multirow{2}{*}{ Ira-Ipaye } & $9.94 \mathrm{E}+0$ & $15.0 \mathrm{E}-02$ & $10.55 \mathrm{E}-02$ & $11.83 \mathrm{E}+0$ & $1.14 \mathrm{E}+0$ \\
& $(10.95 \mathrm{E}+0)$ & $(16.53 \mathrm{E}-02)$ & $(11.60 \mathrm{E}-02)$ & $(13.03 \mathrm{E}+0)$ & $(1.25 \mathrm{E}+0)$ \\
\multirow{2}{*}{ Agboroko } & & $4.75 \mathrm{E}-03$ & & & $1.81 \mathrm{E}-02$ \\
& & $(5.25 \mathrm{E}-03)$ & - & - & $(1.99 \mathrm{E}-02)$ \\
Akesan & $7.06 \mathrm{E}+0$ & $24.58 \mathrm{E}-02$ & $10.55 \mathrm{E}-02$ & $1.53 \mathrm{E}+0$ & $18.30 \mathrm{E}-02$ \\
& $(7.77 \mathrm{E}+0)$ & $(27.08 \mathrm{E}-02)$ & $(11.60 \mathrm{E}-02)$ & $(1.69 \mathrm{E}+0)$ & $(20.13 \mathrm{E}-02)$ \\
\hline
\end{tabular}

Note: values in parentheses are for children, others are for children.

\subsection{Discussion}

The 2016 and $2018 \mathrm{pH}$ values (Table 1 and Table 2), recorded for Ira-Ipaye and Agboroko water samples were below the limit of 6.5 - 8.5 prescribed by WHO for drinking water [42]. Nevertheless, Akesan's 2016 and 2018 values of $6.54 \pm$ 0.47 and $6.53 \pm 0.17$ respectively were within the recommended WHO guideline limits. These observations are consistent with values reported earlier for the Rio Tercero reservoir, Argentina, 6.64 - 7.69 [18]. It reveals the unwholesomeness of the water from Ira-Ipaye and Agboroko watersheds [43].

The $\mathrm{pH}$ of the sediment samples (Table 3 and Table 4) in the three watersheds ranged from $6.14 \pm 0.48-6.90 \pm 0.15(2016)$ and $5.38 \pm 0.22-6.40 \pm 0.38$ (2018) respectively. Earlier workers have reported that $\mathrm{pH}$ is an important variable that influences the behaviour of metals in the environment [28] [44]. Nonetheless, the values recorded here are lower on average compared to the $6.23 \pm$ $0.45-8.73 \pm 0.20$ values reported for sediments harvested from the Ogun river catchments, Ketu, Lagos, Nigeria [28].

Decreases in $\mathrm{pH}$ values have been found to aggravate toxicity in aquatic organisms [45]. Furthermore, $\mathrm{pH}$ is crucial to the partitioning of metals across components of the aquatic ecosystem, for example, it is reported that at $\mathrm{pH}>6$, nickel adsorbs/co-precipitates with iron and manganese (oxy) hydroxides and can also adsorb to suspended organic matter [46].

The concentration profile of metal in the water samples (Tales follows a decreasing concentration order: Agboroko, $\mathrm{Zn}>\mathrm{Cu}>\mathrm{Ni}>\mathrm{Pb}>\mathrm{Cd}$; Akesan, $\mathrm{Zn}>$ $\mathrm{Cu}>\mathrm{Pb} \sim \mathrm{Ni} \sim \mathrm{Cd}$; Ira-Ipaye, $\mathrm{Zn}>\mathrm{Pb}>\mathrm{Cu}>\mathrm{Ni} \sim \mathrm{Cd}(2016)$. The trend for 2018 water samples are respectively, $\mathrm{Zn}>\mathrm{Cu}>\mathrm{Pb} \sim \mathrm{Ni} \sim \mathrm{Cd} ; \mathrm{Pb}>\mathrm{Zn}>\mathrm{Cu}>$ 
$\mathrm{Cd}>\mathrm{Ni}$;n $>\mathrm{Pb}>\mathrm{Cd}>\mathrm{Cu}>\mathrm{Ni}$ for Agboroko, Akesan and Ira-Ipaye watersheds. As evident in Table 1 and Table 2, zinc has the highest concentration in the water samples across the watersheds for 2016, while in 2018 it was lead that the highest concentration during the sampling cycles. Nevertheless, the levels $(\mu \mathrm{g} / \mathrm{L})$ of cadmium, copper, nickel, lead and zinc for 2016 water samples were below the recommended guideline limits prescribed by the World Health Organization for drinking water [42].

However, cadmium, lead and zinc for 2018 (Akesan and Ira-Ipaye) were above the recommended limits $(\mu \mathrm{g} / \mathrm{L})$ of, 5.0, 50.0 and 5000.0 respectively. This is an indication that the water quality of two of the three watersheds under spotlight has deteriorated over the two-year period. This gives cause for concern and there is the need to ascertain the possible anthropogenic activities that could be responsible for the higher pollutant load. The upper Dandenong creek catchment watershed in Victoria, Australia, the urban watershed in California and Michigan's Southeastern watershed experienced a similar profile of heavy metal [14] [22] [47].

In terms of occurrence and distribution, the metals in the sediments (Table 3 and Table 4) follow a decreasing concentration order, $\mathrm{Zn}>\mathrm{Pb}>\mathrm{Cu}>\mathrm{Ni}>\mathrm{Cd}$ for Ira-Ipaye, Agboroko and Akesan respectively (2016 samples). However, the 2018 metal profile is as follows: $\mathrm{Zn}>\mathrm{Pb}>\mathrm{Cu}>\mathrm{Cd}>\mathrm{Ni}$ (Ira-Ipaye); $\mathrm{Pb}>\mathrm{Cu}>$ $\mathrm{Zn}>\mathrm{Ni} \sim \mathrm{Cd}$ (Agboroko); $\mathrm{Pb}>\mathrm{Zn}>\mathrm{Cu}>\mathrm{Cd}>\mathrm{Ni}$ (Akesan). The values reported here are found to be lower than metal concentration values (ng/g) reported for the two watersheds in Abiete-Toko gold district (southern Cameroon), $\mathrm{Cd}(20$ - 231); $\mathrm{Pb}$ (2470 - 8220); $\mathrm{Cu}(8370$ - 48,600); Ni (9150 - 686,000) and Zn $(22,200-199,600)$ respectively [26]. Nevertheless, the concentrations of cadmium, copper and lead levels in Lake Greenwood (South Carolina) sediments experienced a reduction between the three intervening years of 2012 and 2015 [37]. This observation is at variance with the findings of this study. However, the relatively higher metal levels in the sediments compared to the water samples are in consonance with values reported by earlier workers in the Hrazdan River (Armenia) and Lishui River, southern China watershed systems [36] [48].

The t-test statistical analyses (Table 5) of $\mathrm{pH}$ and metal values obtained for water and sediments in the 2016 and 2018 sampling cycles revealed statistically non-significant differences. This is a pointer to the fact that the sources of pollution are unaltered [33]. Nevertheless, the calculated F-statistic, using analysis of variance (ANOVA) (Table 6 and Table 7) for the samples reveal statistically significant differences in the water samples for, copper, nickel and zinc (2016) and for zinc (2018).

Nevertheless, in the sediment samples, $\mathrm{Cd}, \mathrm{Cu}, \mathrm{Ni}, \mathrm{Pb}$ and $\mathrm{Zn}$ are significant across board for 2016 [39]. However, only zinc was statistically significant among the 2018 samples across the three watersheds of Ira-Ipaye, Agboroko and Akesan respectively. These observations are an indication that metal contamination has become widespread in the watersheds within the two-year period of 
2016 to 2018. This is a cause for concern, particularly for the health of aquatic biota in the watersheds [49] [50]. The statistically significant values could also be ascribed to the fact that the three watersheds experienced varying degrees of metal contaminants during the intervening period [43] [51].

The chronic daily intakes (CDIs) and health risk index (HRI) for water usage in 2016 and 2018 sampling cycles are shown in Tables 8-11 respectively. The HRI values recorded are $<1$ for cadmium, copper, nickel, lead and zinc for the 2016 water in the three locations of Ira-Ipaye, Agboroko and Akesan respectively. HRI values of $<1$ are an indication that the health risk associated with the water usage is of no immediate serious health consequences [33] [41] [52] [53].

The 2018 water samples indicate HRI values of cadmium for Ira-Ipaye, 9.94E +0 (adult), 10.95E +0 (children); Akesan, 7.06E +0 (adult), 7.77E+0 (children) respectively. Similarly, HRI values recorded for Ira-Ipaye, are: lead, $11.83 \mathrm{E}+0$ (adult), $13.03 \mathrm{E}+0$ (children); zinc $1.14 \mathrm{E}+0$ (adult) and $1.25 \mathrm{E}+0$ (children) respectively. Similar results for health risk for children and adults have been reported earlier for Lishui River and Shenjia watershed, China [15] [48]. These HRI values are $>1$.

HRI $>1$ values portends adverse health effects [31] [33] [53]. These feed into the narrative expressed earlier by Bornman and co-workers on the rising levels of endocrine-disrupting heavy metal in Africa's water ecosystems [25].

Consequent upon the findings of this study, there is a need for effective management of watersheds, through pollution source control and periodic water quality monitoring. These measures would assist in decontamination, improve functionality as well as protect the watersheds from irreversible degradation.

\section{Conclusion}

The occurrence of metal $(\mathrm{Cd}, \mathrm{Cu}, \mathrm{Ni}, \mathrm{Pb}$ and $\mathrm{Zn})$ in the water and sediment samples at elevated levels in the 2018 cycle is of pressing concern. This is an indication of the increasing trend of metal pollution of the watersheds. Health risk indices of cadmium and lead equally increased from HRI $<1$ to HRI $>1$, between 2016 and 2018. Cadmium and lead concentrations were found to be above the WHO guideline limits for drinking water. The most probable sources of metal contaminants were raw effluent discharges and municipal runoffs. The State and local government authorities are enjoined to protect these watersheds via pollution source control, by regulating the discharge of effluents into these water bodies. Unfortunately, some residents perceive these watersheds as "safe" places to empty their wastes.

\section{Declarations}

The authors have no conflict of interest or competing interests.

\section{Acknowledgements}

The authors are grateful to the Department of Chemistry, Lagos State University, 
Ojo for providing some of the facilities needed to complete this research. We equally appreciate the valuable assistance rendered by Dr. Wusu of Department of Mathematics, Lagos State University, Ojo and Dr. Olawale Raimi, University of Dundee, Scotland.

\section{Conflicts of Interest}

The authors declare no conflicts of interest regarding the publication of this paper.

\section{References}

[1] Hipp, J.A., Ogunseitan, O., Lejano, R. and Smith, C.S. (2006) Optimization of Stormwater Filtration at the Urban/Watershed Interface. Environmental Science \& Technology, 40, 4794-4801. https://doi.org/10.1021/es060520f

[2] United States Environmental Protection Agency USEPA (2008) Application of Watershed Ecological Risk Assessment. EPA/600/R-06/037F, Washington DC.

[3] Huang, X., Chen, H., Xia, F., Wang, Z., Mei, K., Shang, X., Liu, Y., Dahlgren, R.A., Minghua, Z. and Huang, H. (2018) Assessment of Long-Term Watershed Management on Reservoir Phosphorus Concentrations and Export Fluxes. International Journal of Environmental Research \& Public Health, 15, 2169. https://doi.org/10.3390/ijerph15102169

[4] Mohammadi, M., Darvishaan, A.K. and Bahramifar, N. (2019) Spatial Distribution and Source Identification of Heavy Metals (As, $\mathrm{Cr}, \mathrm{Cu}$, and $\mathrm{Ni}$ ) at Sub-Watershed Scale Using Geographically Weighted Regression. International Journal of Soil and Water Conservation Research, 7, 308-315. https://doi.org/10.1016/j.iswcr.2019.01.005

[5] Karr, J.R. (1991) Biological Integrity: A Long Neglected Aspect of Water Resources Management. Ecological Applications, 1, 66-84. https://doi.org/10.2307/1941848

[6] Wichelns, D. (2017) Volumetric Water Footprints, Applied in a Global Context, Do Not Provide Insight Regarding Water Scarcity or Water Quality Degradation. Ecological Indicators, 74, 420-426. https://doi.org/10.1016/j.ecolind.2016.12.008

[7] Muller, A., Osterlund, H., Marsalek, J. and Viklander, M. (2020) The Pollution Conveyed by Urban Runoff: A Review of Sources. Science of the Total Environment, 709, 136125. https://doi.org/10.1016/j.scitotenv.2019.136125

[8] Xia, F., Zhang, C., Qu, L., Song, Q., Ji, X., Mei, K., Dahlgren, R.A. and Zang, M. (2020) A Comprehensive Analysis and Source Apportionment of Metals in Riverine Sediments of a Rural-Urban Watershed. Journal Hazardous Materials, 381, 121230. https://doi.org/10.1016/j.jhazmat.2019.121230

[9] Thorpe, A. and Harrison, R.M. (2008) Sources and Properties of Non-Exhaust Particulate Matter from Road Traffic: A Review. Science of the Total Environment, 400, 270-282. https://doi.org/10.1016/j.scitotenv.2008.06.007

[10] Mcelmurry, S.P., Long, D.T. and Voice, T.C. (2014) Storm Water Dissolved Organic Matter: Influence of Land Cover and Environmental Factors. Environmental Science \& Technology, 48, 45-53. https://doi.org/10.1021/es402664t

[11] Worms, I.A.M., Chmiel, H.E., Traber, J., Tofield-Pasche, N. and Slaveykova, V.I. (2019) Dissolved Organic Matter and Associated Trace Metal Dynamics from River to Lake, under Ice-Covered and Ice-Free Conditions. Environmental Science \& Technology, 53, 14134-14143. https://doi.org/10.1021/acs.est.9b02184

[12] Hao, H., Fenggiong, S., Cao, D., Liu, J. and Jiang, G. (2020) Freezing-Induced Bro- 
mated Reduction by Dissolved Organic Matter and the Formation of Organobromine Compounds. Environmental Science \& Technology, 54, 1668-1676. https://doi.org/10.1021/acs.est.9b07902

[13] Liu, L., Quyang, W., Wang, Y., Tysklind, M., Hao, F., Liu, H., Hao, X., Xu, Y., Lin, C. and Su, L. (2020) Heavy Metal Accumulation, Geochemical Fractions, and Loadings in Two Agricultural Watersheds with Distinct Climate Conditions. Journal Hazardous Materials, 389, 12125. https://doi.org/10.1016/j.jhazmat.2020.122125

[14] Murray, K.S., Rogers, D.T. and Kaufman, M.N. (2004) Heavy Metals in an Urban Watershed in Southeastern Michigan. Journal Environmental Quality, 33, 163-172. https://doi.org/10.2134/jeq2004.1630

[15] Wang, Y., Wen, A., Guo, J., Shi, Z. and Yan, D. (2017) Spatial Distribution, Sources and Ecological Risk Assessment of Heavy Metals in Shenja River Watershed of Three Gorges Reservoir Area. Journal of Mountain Science, 14, 325-335. https://doi.org/10.1007/s11629-016-3838-1

[16] Chen, Y., Huang, H., Ding, Y., Chen, W., Luo, J., Li, H., Wu, J., Chen, W. and Qi, S. (2019) Trace Metals in Aquatic Environments of a Mangrove Ecosystem in Nansha, Guangzhuo, South China: Pollution Status, Sources and Ecological Risk Assessment. Environmental Monitoring \& Assessment, 191, Article No. 629. https://doi.org/10.1007/s10661-019-7732-5

[17] Brown, E.R., Hazdra, J.J., Keith, L., Greenspan, I., Kwapinski, J.B.G. and Beamer, P. (1973) Frequency of Fish Tumors Found in a Polluted Watershed as Compared to Non-Polluted Canadian Waters. Cancer Research, 33, 189-198.

[18] Bonansea, M., Ledesma, C. and Rodriguez, M.C. (2016) Assessing the Impact of Land Use and Land Cover on Water Quality in the Watershed of a Reservoir. Applied Ecology \& Environmental Resources, 14, 447-450.

https://doi.org/10.15666/aeer/1402 447456

[19] Woldeab, B., Ambelu, A., Mereta, S.T. and Beyene, A. (2018) Effect of Watershed Land Use on Tributaries Water Quality in the East African Highland. Environmental Monitoring \& Assessment, 191, Article No. 36. https://doi.org/10.1007/s10661-018-7176-3

[20] Mertz, W. (1981) The Essential Trace Elements, Science, 213, 1332-1338. https://doi.org/10.1126/science.7022654

[21] Mertz, W. (1995) Risk Assessment of Essential Trace Metals: New Approaches to Setting Recommended Dietary Allowances and Safety Limits. Nutrition Review, 53, 179-185. https://doi.org/10.1111/j.1753-4887.1995.tb01548.x

[22] Kellar, C.R., Hassell, K.L., Long, S.M., Myers, J.H., Golding, L., Rose, G., Kumar, A., Hoffmann, A.A. and Pettigrove, V. (2014) Ecological Evidence Links Adverse Biological Effects to Pesticide and Metal Contamination in an Urban Australian Watershed. Journal of Applied Ecology, 51, 426-439.

https://doi.org/10.1111/1365-2664.12211

[23] Jaishankar, M., Tseten, T., Anbalgan, N., Mathew, B.B. and Beeregowda, K.N. (2014) Toxicity, Mechanism and Health Effects of Some Heavy Metals. Interdisciplinary Toxicology, 7, 60-72. https://doi.org/10.2478/intox-2014-0009

[24] Kim, H.S., Kim, Y.J. and Seo, Y.R. (2015) An Overview of Carcinogenic Heavy Metal: Molecular Toxicity Mechanism and Prevention. Journal Cancer Prevention, 20, 232-240. https://doi.org/10.15430/JCP.2015.20.4.232

[25] Bornman, M.S., Aneck-Hahn, N.H., De jager, C., Wagenaar, G.M., Bouwman, H., Barnhoorn, I.E.J., Patrick, S.M., Vanderberg, L.N., Kortenkamp, A., Blumbberg, B., Kimmins, S., Jegou, B., Auger, J., DiGangi, J. and Heindel, J.J. (2017) Endocrine 
Disruptors and Health Effects in Africa: A Call for Action. Environmental Health Perspectives, 125, 085005. https://doi.org/10.1289/EHP1774

[26] Mandeng, E.P.B., Bidjeck, L.M., Bassa, A.Z.E., Ntomb, Y.D., Wadjou, J.W., Doumo, E.P.E. and Dieudonne, L.B. (2019) Contamination and Risk Assessment of Heavy Metals and Uranium of Sediments in Two Watersheds in Abiete-Toko Gold District, Southern Cameroon. Heliyon, 5, e02591. https://doi.org/10.1016/j.heliyon.2019.e02591

[27] Awofolu, O.R., Mbolekwa, Z., Mtshemla, V. and Fatoki, O.S. (2005) Levels of Trace Metals in Water and Sediment from Tyume River and Its Effects on Irrigated Farmland. Water South Africa, 31, 87-94. https://doi.org/10.4314/wsa.v31i1.5124

[28] Adeniyi, A.A., Yusuf, K.A. and Okedeyi, O.O. (2008) Assessment of the Exposure of Two Fish Species to Metals Pollution in the Ogun River Catchments, Ketu, Lagos, Nigeria. Environ Monitoring \& Assessment, 137, 451-458. https://doi.org/10.1007/s10661-007-9780-5

[29] Rose, S. and Shea, J.A. (2007) Environmental Geochemistry of Trace Metal Pollution in Urban Watersheds. Developments in Environmental Science, 5, 99-131. https://doi.org/10.1016/S1474-8177(07)05006-1

[30] Ullah, K.A., Jiang, J. and Wang, P. (2018) Land Use Impacts on Surface Water Quality by Statistical Approaches. Global Journal of Environmental Science \& Management, 4, 231-250.

[31] Pobi, K.K., Satpati, S., Dutta, S., Nayek, S., Saha, S. and Gupta, S. (2019) Sources Evaluation and Ecological Risk Assessment of Heavy Metals Accumulated within Natural Stream of Durgapur Industrial Zone, India, by Using Multivariate Analysis and Pollution Indices. Journal of Applied Water Science, 9, Article No. 58.

https://doi.org/10.1007/s13201-019-0946-4

[32] Yusuf, K.A. and Osibanjo, O. (2006) Trace Metals in Water and Sediments from Ologe Lagoon, Southwestern Nigeria. Pakistan Journal of Scientific \& Industrial Research, 49, 88-89.

[33] Adeniyi, A., Yusuf, K., Okedeyi, O. and Sowemimo, M. (2016) Classification and Health Risk Assessment for Borehole Water Contaminated by Metals in Selected Households in Southwest Nigeria. Journal Water Resource \& Protection, 8, 459-471. https://doi.org/10.4236/jwarp.2016.84039

[34] America Public Health Association (APHA) (1998) Standard Methods for the Examination of Water and Wastewater, APHA, AWWA, and WPCCE. 20th Edition, America Public Health Association, Springfield, New York, Byrd Progress.

[35] Department of Water Affairs and Forestry (DWAF) (1992) Analytical Methods Manual TR 151. Hydrological Research Institute, DWAF, Pretoria.

[36] Petrosyan, V., Pirumyan, G. and Perikhanyan, Y. (2019) Determination of Heavy Metal Background Concentration in Bottom Sediment and Risk Assessment of Sediment and Risk Assessment of Sediment Pollution by Heavy Metals in the Hrazdan River (Armenia). Journal of Applied Water Science, 9, Article No. 102. https://doi.org/10.1007/s13201-019-0996-7

[37] Dukes, A.D., Eklund, R.T., Morgan, Z.D. and Layland, R.C. (2020) Heavy Metal Concentration in the Water and Sediment of Lake Greenwood Watershed. Water, Air, \& Soil Pollution, 231, Article No. 11. https://doi.org/10.1007/s11270-019-4364-x

[38] Adeniyi, A., Dayomi, M., Siebe, P. and Okedeyi, O. (2008) An Assessment of the Levels of Phthalate Esters and Metals in the Muledane Open Dump, Thohoyandou, Limpopo Province, South Africa. Chemistry Central Journal, 2, Article No. 9. 
https://doi.org/10.1186/1752-153X-2-9

[39] Pentecost, A. (1999) Analyzing Environmental Data. Longman, London.

[40] United States Environmental Protection Agency (USEPA) (2011) Exposure Factors Handbook. USEPA, Washington DC.

[41] Khan, K., Lu, Y., Khan, H., Zakir, S., Ihsanullah, I., Khan, S., Khan, A.A., Wei, L. and Wang, T. (2013) Health Risks Associated with Heavy Metals in Drinking Water of Swat, Northern Pakistan. Journal of Environmental Science, 10, 2003-2013. https://doi.org/10.1016/S1001-0742(12)60275-7

[42] WHO (2011) Guidelines for Drinking Water Quality. 4th Edition, World Health Organization, Geneva.

[43] Adeniyi, A., Osifeko, O., Owoade, O., Omotayo, Y., Ajede, E., Ibrahim, A. and Balogun, R. (2014) Metal Burden as Template for Assessing the Quality of Raw Water Sourced from Two Rivers by Lagos State Water Corporation, Nigeria. In: Bhowon, M.G., Jhaumeer-Laulloo, S., Li Kam Wah, H. and Ramasami, P., Eds., Chemistry: The Key to Our Sustainable Future, Springer, Dordrecht, 163-172. https://doi.org/10.1007/978-94-007-7389-9 12

[44] United States Environmental Protection Agency (USEPA) (2017) Framework for Metals Risk Assessment, Risk Assessment Forum. USEPA, Washington DC.

[45] Licata, P., Bella, G.D., Dugo, G. and Naccari, F. (2003) Organochlorine Pesticides, PCBs and Heavy Metals in Tissues of the Mullet Liza aurata in Lake Ganzirri and Straits in Messina (Sicily, Italy). Chemosphere, 52, 231-238. https://doi.org/10.1016/S0045-6535(03)00271-6

[46] Australian Government Initiative (2000) Guidelines for Fresh and Marine Water Quality-Nickel in Freshwater. https://www.waterquality.gov.au

[47] Tiefenthaler, L.L., Stein, E.D. and Schiff, K.C. (2008) Watershed and Land Use-Based Sources of Trace Metals in Urban Storm Water. Environmental Toxicology \& Chemistry, 27, 277-287. https://doi.org/10.1897/07-126R.1

[48] Shen, F., Mao, L., Sun, R., Du, J., Tan, Z. and Ding, M. (2019) Contamination Evaluation and Source Identification of Heavy Metals in the Sediments from the Lishui River Watershed, Southern China. International Journal of Environmental Research \& Public Health, 16, 336-349. https://doi.org/10.3390/ijerph16030336

[49] Nor, Y.M. (1987) Ecotoxicology of Copper to Aquatic Biota: A Review. Environmental Research, 43, 274-282. https://doi.org/10.1016/S0013-9351(87)80078-6

[50] Fatima, M., Usmani, N. and Hossain, M.M. (2014) Heavy Metal in Aquatic Ecosystem Emphasizing Its Effect on Tissue Bioaccumulation and Histopathology: A Review. Journal of Environmental Science \& Toxicology, 7, 1-15. https://doi.org/10.3923/jest.2014.1.15

[51] Adeniyi, A.A., Owoade, O.J., Shotonwa, I.O., Okedeyi, O.O., Ajibade, A.A., Sallu, A.R., Olawore, M.A. and Ope, K.A. (2011) Monitoring Metals Pollution Using Water and Sediments Collected from Ebute Ogbo River Catchments, Ojo, Lagos, Nigeria. African Journal of Pure and Applied Chemistry, 5, 219-223.

[52] Chanpiwat, P., Lee, B.-T., Kim, K.-W. and Sthiannopkao, S. (2014) Human Health Risk Assessment for Ingestion Exposure to Groundwater Contaminated by Naturally Occurring Mixtures of Toxic Heavy Metals in Lao PDR. Environmental Monitoring \& Assessment, 186, 4905-4923. https://doi.org/10.1007/s10661-014-3747-0

[53] Farokhneshat, F., Mahvi, A.H. and Jamali, Y. (2016) Carcinogenic and Non- Carcinogenic Risk Assessment of Chromium in Drinking Water Sources in Birjand, Iran. Research Journal of Environmental Toxicology, 10, 166-171. https://doi.org/10.3923/rjet.2016.166.171 